FINANCIAL SYSTEM AND CORPORATE GOVERNANCE

AROUND THE WORLD.

LESSONS FOR EMERGING MARKETS

\author{
Nicola Miglietta \\ Aggregated Professor of Business Management, Ph.D. University of Turin, \\ Department of Management, Italy
}

Enrico Battisti

Ph.D. Student in Business and Management. University of Turin, Department of Management, Italy

\begin{abstract}
This article aims to scrutinize features of models of corporate governance across the globe. The purpose of the article is to find an optimal model that can be employed and developed by companies from emerging markets. Corporate governance is closely connected with a financial system of a country. Usually, corporations appear to partnerships between managers-employees that take part in corporate governance and form human capital assets and external investors. Main goal of managers is to maximize stockholders' wealth. According to US and UK laws, managers must serve the interests of stockholders. From this point of view, it is assumed that the Board of Directors represents stockholders' interests. But laws and traditions vary among different countries. It is widely accepted to distinguish corporate governance between countries with market-based and bank-based systems. The article is divided into two parts. The first part studies the interconnection between corporate finance and corporate governance. The second part explores corporate governance models of developed countries (Anglo-Saxon countries, Germany, Japan, and Italy) and emerging countries (Brazil, Russia, India, China) in attempt to find out differences among them. The conclusion presents key elements of corporate governance system and shows that the optimal model for emerging markets should be based on the system of Network Governance that take into account interests of all the stakeholders.
\end{abstract}

\title{
JEL: G30
}

Key words: emerging capital markets, corporate governance, Network Governance.

\section{Introduction}

The structure of ownership and the resulting system of corporate governance varies according to its own financial system of reference.

Financial systems can be divided into two categories: market-based systems and bank-based systems. In market-based systems companies are typically set as public companies, which collect cash mainly by the issue of corporate bonds and, only partially, recurring to bank loans; in bank-based systems, where private companies prevail, most capital is raised through bank loans, because of the low level of development of capital markets. In geographical terms, included among the marketbased countries are the United States, the United Kingdom and Asia, while Europe and Japan are included in the bank-based countries (Allen, Chui, Maddaloni, 2008).

These differences have historical roots, related to the different legal systems that have been adopted by each country. Indeed it is recognizable a correlation between the legal system in force in a specific reality and the degree of development of its financial markets. In countries with a system based on Common Law (like England), which guarantees a high level of investors' protection, there has been a significant development of the capital market. On the other hand, in countries where it is in force a system based on Civil Law (like most of those in Europe), the spread of the financial market is very limited. In the international scene these differences have led to a different development in Corporate Governance systems. 
The most common model of corporate governance is a product of developed markets (like Anglo-Saxon countries, Germany, Japan and Italy), where ownership and control are often separated (agency contract) and legal mechanisms and institutional context protect owners' interest (Peng, 2003). Differently, in emerging markets the institutional context makes the enforcement of agency contracts more onerous and difficult (Young et al., 2008).

The paper is organized as follows.

In the first part we have examined the relations between Corporate Finance and Corporate Governance. In the second part we have observed the main Corporate Governance Systems, from developed economies to emerging markets. In the third and last part, we have identified some critical factors common to models of corporate governance in Emerging Markets and, in a system of Network Governance, we have verified the existence of an optimal model of Corporate Governance that could be a datum point for Emerging Markets.

\section{Relations between Corporate Finance and Corporate Governance}

The United States, United Kingdom and Asia (Indonesia, Hong Kong, Korea, Malaysia, Singapore, Thailand, Taiwan) have a market-based financial system with large stock market and large corporate bond market. Germany, France, Italy, Spain and Japan have a bank-based financial systems where bank financing plays an important role and stock market is relatively small. The differences between the financial systems have different historical origins and evolutionary impacts for the different countries also in terms of corporate governance.

Corporate Governance represents a system of prescriptive rules that regulate, within a corporation, relationships between the shareholder-owners, which bestow the resources required to carry out the business, and the management who is entrusted the company's administration (Keasy, Thompson, Wright, 1997). In particular in emerging markets the empirical literature shows that a separation of control and ownership is the exception worldwide rather than the norm (Demsetz, Lehn, 1985; La Porta, López-de-Silanes, Shleifer, 1999; Claessens, Djankov, Lang, 2000; Becht, Mayer, 2001; Franks, Mayer, 2001; Faccio, Lang, 2002; Franks, Mayer, Wagner, 2006; Aguilera et al., 2011). The relationship between shareholders and managers is defined of agency and it represents a contractual form in which an individual (principal) charges another one (agent) with carrying out a set of tasks that entail management powers usable in a discretionary way (Jensen, Meckling, 1976; Shleifer, Vishny, 1997).

The problem concerning the compliance of the managers' behaviour to meet the interests of shareholders (or owners) is connected with the theory of the separation of ownership and control and is the basis of several studies and related international contributions, carried out since the Sixties, about companies' behaviour (Baumol, 1962; Williamson, 1964).

To the many advantages which is associated the separation between ownership and control correspond some critical aspects. These aspects are linked with the nature of the agency relationship, in reference to the compliance of interests between principal-agent and in the asymmetric information between the parties that may generate opportunistic behaviours in the pre-contractual phase (adverse selection) and in the post-contractual one (moral hazard) (Melis, 1999).

The Agency Theory highlights how managers can pursue their personal interests to the detriment of the shareholders because they can take advantage of the discretion to chase their own interests, the informative asymmetry to hide them and that they can rely upon the right to be paid even in the case of negative results (Grossman, Hart, 1983; Fama, 1980; Bradley et al., 1999).

The instruments of Corporate Governance are implemented to solve this problem, which are:

- the arrangement of a Board of Directors, which is configured as an organ of protection for shareholders; its task is to supervise the management behavior in order to ensure that its conduct actually allows the satisfaction of shareholders' interests (that is the optimization of the shares' value) (Monks, Minow, 2004); 
- the introduction of incentive systems, through the arrangement, within the overall remuneration of managers, of a variable component, based on the performance achieved by the company (Demsetz, Lehn, 1985).

The relationship between Corporate Finance and Corporate Governance is observed in the fact that the mechanisms of corporate governance offer a kind of reassurance concerning the effective achievement of the expected remuneration to those who want to invest financial resources into the enterprise. Traditionally the literature identifies two models of governance, which are opposite to each other: the Anglo-Saxon model, typical of the United States, which sees a prevalence of public companies and a widespread of ownership, and the Rhine model, typical of Germany and also common, with some differences, in Japan, which sees firms that have a more concentrated ownership structure, which allows a tight control on management (Forestieri, 1998; Nestor, Thompson, 2000; Zampi, 1995).

To represent the corporate governance models in the world it is necessary to set a clear separation between two basic interpretive schemes (Mayer, 1992):

- the outsider system, in which it is identified a scheme based on the idea that the capital market is the most efficient mechanism for regulating conflicts of interest in between shareholders and managers; this is typical in the Anglo-Saxon model;

- the insider system, where the search for a compromise of interests prevails, directly within the corporation, among the many stakeholders and it is attributable to the Rhine-Japanese model.

Similarly the corporate bodies may be structured in systems (Fortuna, 2001):

- one-tier, characterized by a single Board of Directors with functions of management and of corporate control;

- $\quad t w o-t i e r$, structured in a Management Board with management tasks, and a Supervisory Board with control tasks.

Below we analyse the corporate governance models common in major developed economies.

\section{The Developed Markets' Corporate Governance Models}

\section{Anglo-Saxon Countries}

The American capitalist system (United States) is typically market-oriented; it sees a clear prevalence of Corporations as company model, characterized by a greatly fragmented ownership and a high degree of transparency towards the market. The strengths of this system are summarized by the fact that on one hand it allows the gathering of capital at competitive conditions and at low cost (essential conditions for value creation) and on the other hand it guarantees for a management oriented at a long-term growth, since its action isn't subjected to the pressure of a single or a few shareholders.

The system of governance adopted by U.S. corporations belong to the one-tier model (Fortuna, 2001); It envisages the existence of a single administrative body (the Board of Directors), appointed by the shareholders to whom are entrusted with both the management function and the control function.

It is composed both of internal directors who deal with the management of the company, that are responsible to report to the shareholders on the activity's evolution, and external directors, without executive functions, who have only powers of control (Franks, Mayer, Renneboog, 2001).

The English capitalist system (United Kingdom), like the U.S. one, is configured as a "managerial capitalism". In fact it is characterized by a high degree of diffusion of ownership of large corporations which are subsidized also significantly by institutional investors, such as insurance companies and investment funds (Mallin, 2006). The existence of a capital market highly fluid and large (marketoriented system) characterizes the Anglo-Saxon model of corporate governance. Even British companies have adopted a one-tier system of corporate governance, where there is a board within which government and control functions are carried out (Harvey, Maclean, Press, 2005). 
The Germany capitalist system is characterized by companies that have a very concentrated ownership structure, in which a key role is played by banks. They hold significant equity interests, as well as being the main source of funding of the business system (Franks, Mayer, 2001; Franks et al., 2006). The key role of the intermediary bank (so called Hausbank) is characterized by a very broad and articulate practicality and it had effects both on the financial structure of companies, determining the undercapitalization and entailing a prevalence of debt compared with the capital risk, and on the Germany corporate governance structure. Indeed power of control and influence of the Board of Directors, exercised trough special representatives, are granted to credit institutions by virtue of the direct holdings' in companies and loans supplied (Edwards, Nibler, 2000).

The Germany system of corporate governance is defined two-tier, as it provides for the establishment within companies of two organs that are assigned distinct functions: the Management Board, which deals exclusively with the business management, and the Supervisory Board, to whom is bestowed the control function, half of whose members represent employees' interest, while the other half is often made up of executives of investment banks representing shareholders' interest (Douma, 1997).

\section{Japan}

The Japanese capitalist system is focused on a business model unique in the world: the Keiretsu. It consists of a network of companies, linked by a system of cross-shareholdings, both vertical (held in supplier companies and-or small customer ones), and horizontal (held or in other companies operating in other industries, or in banks, financial institutions and insurance companies), which establish long-term relationships just to maintain each one's autonomy with the common goal of ensuring wealth creation and sustainability of the company (Bertoli et al., 1994). Up to mid-90s the Japanese capitalist system was heavily bank-based (Hoshi, Kashyap, Fischer, 2001).

Indeed the relationships that Keiretsu established with the Main Bank were central to its operation. The Main Bank was in charge of providing capital to individual business realities from which the group was composed of and, at the same time, it held a significant equity interest (Hitt, Lee, Yucel, 2002). This has had an impact both on the ownership structure of Japanese companies - as a large part of the shares were held by banks and other financial intermediaries, another part, equally significant, was represented by the cross-holdings' system, while only a residual minority part was held by private shareholders - and on the system of governance, as the priority of the management was to protect the interests of the company, considered as an economic entity distinct from the shareholders.

From the mid-90s following the economic crisis that has led to a series of failures in the bankinginsurance sector and that of the Keiretsu hanging on intermediaries involved (Bremner, Thornton, Kunii, 1999), the Japanese capitalist system began to move away from an exclusively bank-based system. It assumed a greater openness to the market, which has entailed an increase in the weight of private shareholders in the ownership structure of the Keiretsu and the consequent transformation of the model of corporate governance that, at present, is set up as a hybrid system. In this system both the interests of the banks, which still hold some shares, as well as those of private shareholders must be protected.

\section{Italy}

The system of corporate governance spread in Italy is closely related to the structure of national capitalist system, characterized by the predominance of family-owned SMEs (Small and Medium Enterprises), for the lack of the stock market's development and a strong connection between business and banking system.

The governance structure of Italian companies is more similar to the Germany model rather than the Anglo-Saxon one precisely because of the high concentration of ownership and the low degree of openness to capital markets. This structure of governance of Italian companies is the result of the development that historically the Italian capitalism has had. 
The present governance model is of entrepreneurial-family kind: the majority shareholders, who practise an active role in the management of the company, are in most cases embodied by small family groups (Fiori, 2003; Mengol et al., 2009).

The government and management body of the company is the Board of Directors, appointed by the Ordinary Shareholders' Meeting, which has the possibility to revoke (or to re-elect) directors. In turn, the Board of Directors appoints, within itself, a Chief Executive Officer or an Executive Committee, which is entrusted with management functions. The governing body is accompanied by a supervisory body. Furthermore the Italian legal system recognizes to the limited company the possibility to choose among three different models of governance:

- the traditional one, which envisages that the Board of Directors is supported, as monitoring system, by a Board of Statutory Auditors, devoid of auditing assignments, entrusted to a legal auditor or an external auditing business;

- the dualistic one (dual-board), in which the Board of Directors takes the form of the Management Board and is supported by a Supervisory Board, which is entrusted with control assignments (this governance model is similar to that of Germany);

- the one-tier, in which there isn't a Board of Auditors and the control functions are entrusted to the Audit Committee, internal to the same Board of Directors (this governance model is similar to the Anglo-Saxon one).

\section{The Emerging Markets' Corporate Governance Models}

Over the past two decades there has been a rapid growth of emerging economies, among which Brazil, Russia, India and China (BRIC) have recorded a growth rate particularly significant. Corporate governance has become a basic mean for improving corporate performance and for the development of market. In particular, the literature shows that there are several institutional features that are important in corporate finance and governance decisions (Fan, John Wei, Xu, 2011).

1. Government involvement in business. The quality of public governance is of first order relevance in determining the governance of the corporate sector (Fan, Rui, Zhao, 2008). Emerging markets, while presenting problems of a political-institutional matter, are characterized by a massive presence of the State in their economy. In particular, governments, through taxation, regulation, and state ownership, influence and control various aspects of business: from output (production process), to input, (for example labour, energy, infrastructures, and financing) (Fan, John Wei, Xu, 2011).

Indeed, the empirical evidence shows the existence of phenomena of collusion between entrepreneurs-managers and politicians (Fisman, 2001), which results in the creation of complex organizational structures, characterized by lack of transparency and a weak system of governance (Leuz, Oberholzer-Gee, 2006; Fan, Wong, Zhang, 2007, 2009, Jiang, Lee, Yue, 2010).

In this sense, given the intense government involvement in business, the quality of government policies is a critical impacting factor of emerging market firms (Shleifer, Vishny, 1997; La Porta et al., 1999). Government restrictions on transferring firm ownership to private sectors highlight another essential limit of emerging market firms.

The impact of the public actor in the economy of developing countries comes to light in the high level of shareholdings held by the State in several important enterprises (State Owned Enterprises, SOEs), which makes difficult the realization of a privatization process through the imposition of restrictions on the transfer of shares to the private sector (Black, Kraakman, Tarassova, 2000; Stiglitz, Muet, 2001).

2. Financial market development. A growing number of contributions indicate that economic growth depends on the distribution of control over capital assets (Levine, Ross, 1997; Rajan et al., 1998). In this sense, in a well-functioning economy, there is specialization in investment and in management and the role of financial market becomes essential (Dyck, 2001).

The Emerging Markets (BRICs) are characterized by: 
- a limited development of financial markets (La Porta et al, 2002);

- a prevalent control exercised by the Government on banking systems (La Porta et al., 2002);

- $\quad$ a reduced ability of the legal system to protect investors (Chen, Chen, Wie, 2009).

These features represent a structural weakness of the Corporate Governance Systems (Morck et al., 2005; Khanna, Yafeh, 2007). Moreover, as financial market development fails to keep up, emerging market firms have inadequate access to external capital (debt or equity) (Khanna, Yafeh, 2007). Often, applying for external financial resources involves non-price mechanisms such as building relationships with government officers and bankers (Fan, John Wei, Xu, 2011).

Further below we analyze the corporate governance models common in major emerging markets.

Brazil

Most of Brazilian companies have a highly concentrated ownership structure, in which the majority of shares are held by or a single shareholder, or a small group of investors.

Two factors have been supporting the high concentration of control: on one hand, the nationalization of several private companies, which occurred since the 70s which has led that, in the late $80 \mathrm{~s}$, the State held the ownership of about 600 Brazilian companies (Tardivo, Schiesari, Miglietta, 2012); on the other hand the fact that companies issue shares that grant their holders the right to vote (defined shareholders insiders) to a lesser extent than those that have not the right to vote (whose holders are defined shareholders outsiders) (Leal et al., 2000).

Moreover, the Brazilian legal system recognizes a still relatively limited protection to minority shareholders. These factors have produced a series of structural weaknesses in terms of corporate governance that are still observed despite the recent changes done, made necessary by the rapid growth of the country and the globalization of markets (Gorga, 2006).

The main critical factors are related to the low degree of transparency (as the limited distribution of company law highlights), to the small size of the Board of Directors, within which in many companies there are neither independent directors, nor Control Committees (Black, Gledson de Carvalho, Gorga, 2010).

\section{Russian Federation}

The subject of corporate governance in Russian Federation (Russia) has developed quite recently for historical reasons, when during the transition from socialism to the capitalistic economic system privatizations started first, then policy turned up to be unpopular (Bartha, Gilles, 2006). In most of the Russian companies there is not a clear separation of roles between the Board of Directors and management, as the dominant shareholder (defined as «insiders») and top management are the same.

This is a distinctive characteristic both of the governance system of the great industrial and financial groups (the FIGs) and the other major corporate groups, and of the small and medium-sized enterprises born as a result of the privatization process (Vijugin, 2004).

However, even in companies in which the owner is an «outsider» and the managerial function is entrusted to a team of managers, the main shareholder has the right to conduct and control the operations carried out by the Board of Directors and to use in a discretional way company information, taking shape, therefore, of an «insider», without having formally managerial positions.

Minority shareholders have the role of «weak outsiders», as they are kept out of the managerial process carried out by «insiders». The role played by the Non-Governmental Associations (NGOs) in this country is essential for the future development of the governance system. In fact they are interested in identifying new corporate governance structures, through research carried out with the support of political institutions, promoting the adoption of new and better models of corporate control, configured as intermediaries between companies, institutions and professional experts (Bartha, Gilles, 2006). 
The Indian financial market is highly developed. In fact 22 stock exchanges operate in the country and the number of foreign companies in India has nearly tripled in less than a decade (from 772 in 1997 to 1,654 in 2004). Therefore the regulation of the financial market has reached a high level of structure and, in 1992, a specific legislation was adopted, the Securities and Exchange Board of India Act (SEBI), which aims to regulate the functioning of the securities market and to introduce more advanced governance systems (Goswami, 2002; Dahiya, 2006).

However, the reform of corporate governance has met with obstacles due to the limited availability of qualified independent directors and the opposition by the dominant shareholders (Barton, Coombers, Wong, 2004; Rajagopalan, Zhang, 2008). The innovations introduced by SEBI covered a number of aspects (Dahiya, Gupta, 2003), starting from the composition of the Board of Directors.

Under reform was also the system of remuneration of non-executive and independent directors, as SEBI established that it is up to the Board to fix the level of remuneration of those individuals, which must, then, be approved by shareholders in assembly. Finally the role and powers of the Audit Committee were defined, which has the assignment of monitoring the financial reporting process, the quality of accounting, the risk management and the internal control system.

Moreover in 2005 the Ministry of Corporate Affairs, in collaboration with other national institutions, founded the National Foundation of Corporate Governance in order to further improve the corporate governance mechanisms in India and to promote the convergence to international standards in relation to accounting, the audit procedures and financial disclosure.

\section{China}

China appears to be the largest economy in Asia and a leading country in the category of BRIC. The characteristics of the Chinese model of corporate governance are the result of the development originated after the adoption, in the $90 \mathrm{~s}$, by the Government of a new economic policy, known as «2-R» (Retain and Retreat). It envisaged that the state maintained control of SOEs (State Owned Enterprises), large public companies operating in the most strategic industries and, at the same time, gave way to private control of small and medium-sized enterprises active in the most competitive sectors (Walter, Howie, 2003; Green, Liu, 2005). The development of the stock market has been of essential importance for the implementation of the policy. In fact, it is configured both as a vehicle for raising funds needed to support the SOEs, and allowed the government to transform public enterprises in modern companies, while maintaining a majority stake in them (Liu, Sun, 2006).

The current system of corporate governance is the two-tier type, derived from Germany, which predicts the existence of a Board of Directors and a Supervisory Board, with respect to which, however, there are differences (Tam, 1999). In fact in the Chinese model tighter assignments are attributed to the Supervisory Board as it has both the power of appointment and removal of directors of the board, while it has not any operational mechanisms that will enable the effective discharge of the monitoring function to it formally attributed.

\section{Does it exist an optimal model for Emerging Markets?}

In the first part of this work we have explored some of the main models of corporate governance in the world and the different systems of corporate control resulting from the major or minor weight of capital market and financial institutions. The most widespread model is the Anglo-Saxon one that it is based on financial market. However most part of companies in the world are family owned and they are under the control of one or more family groups. The recent and long-lasting crisis of financial system imposes some reflections about the corporate governance's future, in particular, for Emerging Markets. In this sense, we have identified some common elements in the systems of governance in Emerging Markets and some of the benefits that a virtuous model of corporate governance can lead to Investors and Companies (Figure 1). 


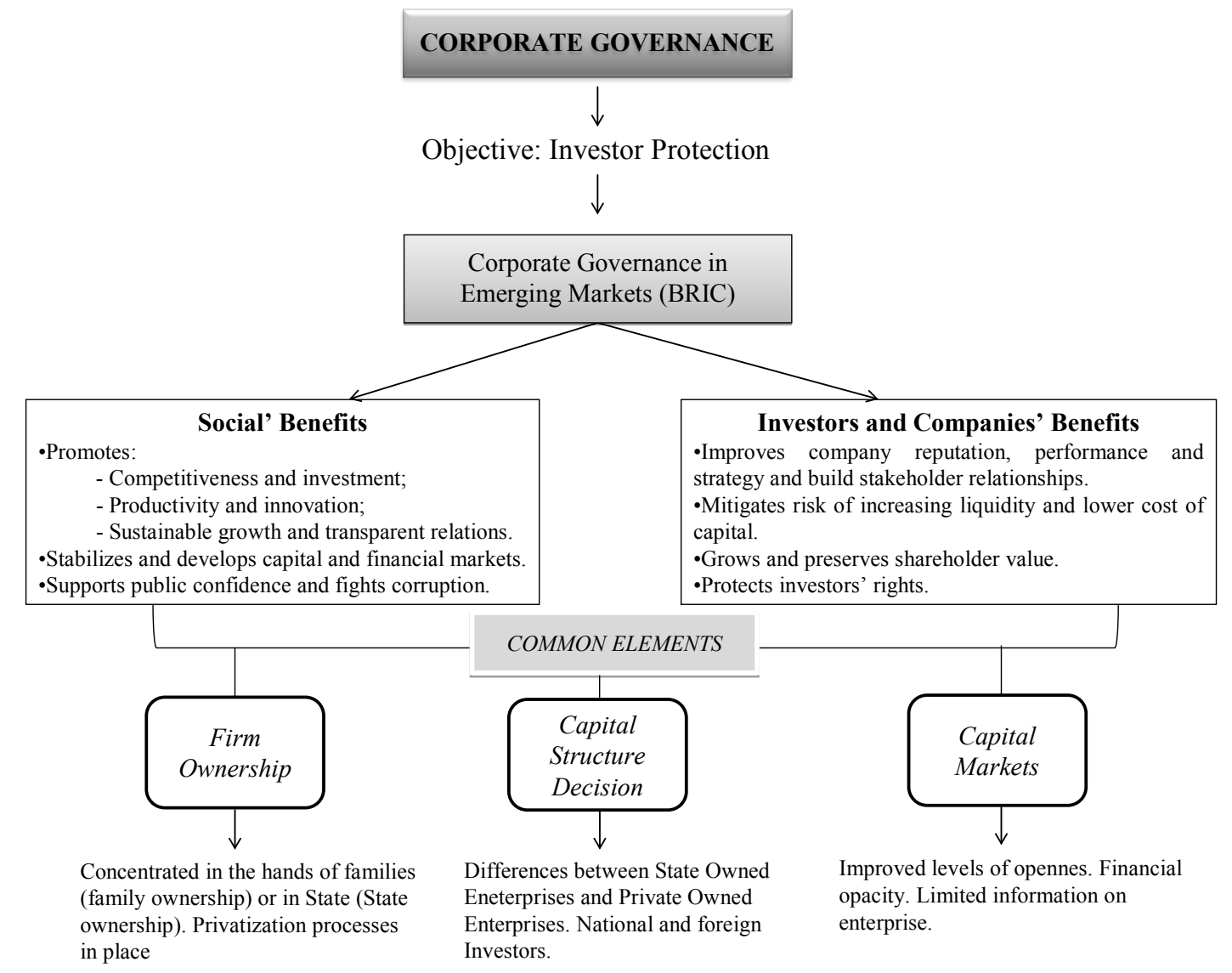

Figure 1. Corporate Governance in Emerging Markets

Source: our elaboration.

The corruption risk inside of companies and, as a consequence, the failure of corporate governance are real threats for the future of corporations therefore an optimal model of Corporate Governance should:

- identify responsibilities and the relative sanction mechanisms;

- $\quad$ protect the company reputation;

- create a greater separation between the role of control and the managerial power by sensitizing the responsibilities of managers and investor owners;

- guarantee the independence of the committee of auditing, nomination and remuneration;

- spread a culture of control by improving the quality and the flow of information inside the company structure.

Furthermore the corporate governance systems must be characterized by the confidence of the international financial community and then communicate efficiently openness, responsibility, absence of compromises and, in particular, attention to the behavioural distortions that characterizes the managers' decision-making process (Miglietta, Battisti, 2011). For example, a system of incentives linked to the future of the company, not necessarily based on the stock option mechanism, could reveal itself suitable for a decrease of the chief executive officer's conflicts of interest.

We believe that an optimal model of corporate governance should be based on a system of Network Governance (Nohria, 1992; Ring, Van de Ven, 1992; Jones, Hesterly, Borgatti, 1997). Indeed, network governance could represent an effective way to reform the corporate governance, by increasing board responsibility and competency. In fact, network governance is based on an active involvement of organizational stakeholder and multiple boards with different special attributions and in this way it allows the mitigation of the operational risk. The network works like human brain that it composed by several changing areas that work together and there is no an hierarchical control centre. 
Moreover the structure of network allows the achievement of the following objectives (Pirson, Turnbull, 2010):

- improvement of the accuracy of information;

- $\quad$ enhancement of the control inside the company;

- decrease of the overload of useless information;

- mediation of conflicts and unethical behaviour.

From the point of view of the first objective the network governance can reduce the communication risks by using parallel communication channels: these channels are managed by stakeholder councils that cross check all the information they receive from management; in this way the firm is able to capture higher quality information.

The second objective can be achieved by a strengthened monitoring of the risk and an increased number of controllers.

In order to reduce the overload of tasks and information the firm could introduce a separated control centre that operates with the committee of auditing, nomination and remuneration; another way to achieve this objective is to divide the governance task among different geographical areas. Finally the conflicts of interest could be mediated by systems of checks and balances in order to prevent systematic power abuse by the rulers. We can assert that the network governance is not the absolute solution to financial crisis and bankruptcy of firms (like, for example, Enron and Parmalat) but it represents an effective way to avoid future crisis by installing warning systems that use the intelligence of stakeholder: board could draw important conclusions if the firms establish a systematic stakeholder feedback independent from management (Pirson, Turnbull, 2010).

In conclusion we can highlight that there isn't an optimal model of Corporate Governance, but there is a virtuous model of Corporate Governance, that in a system of Network Governance, which could provide a reference point for the Emerging Markets.

\section{References}

1. Aguilera, R.V., Kabbach de Castro, L.R., Lee, L.J., You, J. (2011), Corporate Governance in Emerging Markets, Oxford: Oxford University Press

2. Allen, F., Chui, M., Maddaloni, A. (2008), Financial Structure and Corporate Governance in Europe, the USA and Asia, in Freixas X., Hartman P., Mayer C., (edited by), Handbook of European Financial Market and Institutions, Oxford: Oxford University Press

3. Bartha, P., Gilles, J. (2006), Corporate Governance in Russia: is it really needed?, in Mallin C.A. (edited by), Handbook on International Corporate Governance. Country analyses, Edward Elgar Publishing.

4. Barton, D., Coombers, P., Wong, S.C.Y. (2004), Asia's governance challenge, McKinsey Quarterly, 2 (2004) 54-61.

5. Baumol, W.J. (1962), On the Theory of the Expansion of the Firm, American Economic Review, 52(5) (1962) 1078-1087.

6. Becht, M., Mayer, C. (2001), Introduction, in Barca, F., Becht, M. (edited by), The Control of Corporate Europe, Oxford: Oxford University Press.

7. Bertoli, G., Farinet, A., Guerini, C., Mauri, A.G., Songini, L. (1994), Il capitalismo industriale nelle economie avanzate: Europa, Stati Uniti e Giappone, Milano: Egea.

8. Black, B.S., Gledson de Carvalho, A., Gorga, E. (2010), Corporate governance in Brazil, Emerging Market Review, 11(01) (2010) 21-38.

9. Black, B.S., Kraakman, R., Tarassova, A. (2000), Russian Privatization and Corporate Governance: what went wrong?, Standford Law Review, 52 (2000) 1731-1808. 
10. Bradley, M., Schipani, C.A., Sundaram, A.K., Wlash, J.P. (1999), The purposes and accountability of the corporation in contemporary society: Corporate Governance at a crossroads, Law and Contemporary Problems, 62(3) (1999) 9-86.

11. Bremner, B., Thornton E., Kunii I.M. (1999), Fall of a keiretsu, Business Week, (15 March 1999).

12. Chen, K.C.W., Chen Z., Wie K.C.J. (2009), Legal protection of investors, corporate governance and the cost of equity capital, Journal of Corporate Finance, 15(3) (2009) 273-289.

13. Claessens, S., Djankov, S, Lang, L.H.P. (2000), The Separation of Ownership and Control in East Asian Corporations, Journal of Financial Economics, 58(1) (2000) 81-112.

14. Dahiya, S.B. (2006), Corporate Governance developments in India, in Mallin, C.A. (edited by), Handbook on International Corporate Governance. Country analyses, Camberley Surrey: Edward Elgar Publishing.

15. Dahiya, S.B., Gupta, D. (2003), The current state of corporate governance in India, in Raghbendra, J. (edited by), Indian Economic Reforms, Basingstoke: Palagrave Macmillan.

16. Demsetz, H., Lehn, K. (1985), The structure of corporate ownership: causes and consequences, Journal of Political Economy, 93(6) (1985) 1155-1177.

17. Douma, S. (1997), The two-tier system of corporate governance, Long Range Planning, 30(04) (1997) 612-615.

18. Dyck, M. (2001), Privatisation and Corporate Governance: Principles, Evidences and Future Challenges, The World Bank Research Observer, 16(1) (2001) 59-84.

19. Edwards, J., Nibler, M. (2000), Corporate Governance in Germany: the role of banks and ownership concentration, Journal of Economic Policy, 15(31) (2000) 237-260.

20. Faccio, M., Lang, L.H.P. (2002), The Ultimate Ownership of Western European Corporations, Journal of Financial Economics, 65(3) (2002) 365-395.

21. Fama, E.F. (1980), Agency problems and the theory of the firm, Journal of Political Economy, 88(2) (1980) 288-307.

22. Fan, J.P.H., John Wei, K.C., Xu, X. (2011), Corporate finance and governance in emerging markets: A selective review and an agenda for future research, Journal of Corporate Finance, 17 (2011) 207-214.

23. Fan, J.P.H., Rui, M., Zhao, M. (2008), Public governance and corporate finance: Evidence from corruption cases. J. Comp. Econ, 36 (2008) 343-364.

24. Fan, J.P.H., Wong, T.J., Zhang, T. (2007), Political connected CEOs, corporate governance and post-IPO performance of China's partially privatized firms, Journal of Financial Economics, 84(2) (2007) 330-357.

25. Fan, J.P.H., Wong, T.J., Zhang, T. (2009), Institutions and organizational structure: the case of state-owned corporate pyramids, Hong Kong: The Chinese University of Hong Kong.

26. Fiori, G. (2003), Corporate Governance e qualità dell'informazione esterna d'impresa, Milano: Giuffrè.

27. Fisman, R. (2001), Estimating the value of political connections, American Economic Review, 91(04) (2001) 1095-1102.

28. Forestieri, G. (1998), La Corporate Governance negli schemi interpretativi della letteratura, in Airoldi, G., Forestieri, G., Corporate Governance. Analisi e prospettive del caso italiano, Milano: Etas Libri.

29. Fortuna, F. (2001), Corporate Governance: soggetti, modelli e sistemi, Roma: Franco Angeli.

30. Franks, J., Mayer, C. (2001), Ownership and Control of German Corporations, Review of Financial Studies, 14(4) (2001) 943-977. 
31. Franks, J., Mayer, C., Wagner, H.F. (2006), The Origins of the German Corporation: Finance, Ownership and Control, Review of Finance, 10(4) (2006) 537-558.

32. Gorga, E. (2006), Culture and corporate law reform: a case study of Brazil, Journal of International Economic Law, 27 (2006) 803-905.

33. Goswami, O. (2002), Corporate governance in India, in Taking action against corruption in Asia and the Pacific, Asian Development Bank.

34. Green, S., Liu, G.S. (edited by) (2005), Exit the Dragon?: Privatization and State Control in China, Wiley.

35. Grossman, S.J., Hart O.D. (1983), An Analysis of the Principal Agent Problem, Econometrica, 51(1) (1983) 7-45.

36. Harvey, C., Maclean, M., Press, J. (2005), Business elites and corporate governance in France and the UK. French Politics, Society and Culture, Basingstoke: Palgrave Macmillan.

37. Hitt, M.A., Lee, H., Yucel, E. (2002), The importance of social capital to the management of multinational enterprises: relation networks among Asian and Western Firms, Asia Pacific Journal of Management, 19(02) (2002) 353-372.

38. Hoshi, T., Kashyap, A.K., Fischer, S. (2001), Corporate Financing and Governance in Japan: The Road to the Future, Cambridge: MIT Press.

39. Jensen, M.C., Meckling, W.H. (1976), Theory of the Firm: Managerial Behavior, Agency Costs and Ownership Structure, Journal of Financial Economics, 3(4) (1976) 305-360.

40. Jiang, G., Lee, C.M., Yue, H. (2010), Tunneling through intercorporate loans: the Chinese experience, Journal of Financial Economics, 98(01) (2010) 1-20.

41. Jones, C, Hesterly, W.S, Borgatti, S.P. (1997), A General Theory of Network Governance: Exchange Conditions and Social Mechanisms, Academy of Management Review, 22(4) (1997) 911-945.

42. Keasy, K., Thompson, S., Wright M. (1997), Corporate Governance: Economic and Financial Issues, Oxford: Oxford University Press.

43. Khanna, T., Yafeh, Y. (2007), Business groups in emerging markets: paragons or parasites? Journal of Economic Literature, 45(2) (2007) 331-372.

44. La Porta, R., López-de-Silanes, F., Shleifer, A. (1999), Corporate Ownership Around the World, The Journal of Finance, 54(2) (1999) 471-517.

45. La Porta, R., Lopez-de-Silanes, F., Shleifer, A., Vishny, R. (2002), Government ownership of banks, Journal of Finance, 57(01) (2002) 265-301.

46. Leal, R.P.C., Carvalhal-da-Silva, A.L., Valadares, S.M. (2000), Ownership, control and corporate valuation of Brazilian companies, Proceedings of The Latin American corporate governance roundtable.

47. Leuz, C., Oberholzer-Gee, F. (2006) Political relationship, global financing and corporate transparency, Journal of Financial Economics, 81(02) (2006) 411-439.

48. Levine, R. (1997), Financial Development and Economic Growth: Views and Agenda, Journal of Economic Literature, 35(2) (1997) 688-726.

49. Liu, G.S., Sun, P. (2006), State-dominated corporate governance system in transition: the case of China, in Mallin C.A. (edited by), Handbook on International Corporate Governance. Country analyses, Camberley: Edward Elgar Publishing.

50. Mallin, C.A. (edited by) (2006), Handbook on International Corporate Governance. Country analyses, Camberley Surrey: Edward Elgar Publishing.

51. Mayer, C. (1992), Corporate Finance in The New Palgrave Dictionary of Money \& Finance, The London: Macmillan Press.

52. Melis, A. (1999), Corporate Governance, Torino: Giappichelli. 
53. Mengoli, S., Pazzaglia, F., Sapienza, E. (2009), Effect of Corporate Ownership in Italy: Is it still Pizza, Spaghetti and Mandolino?, Corporate Governance: an International Review, 17(05) (2009) 629-645.

54. Miglietta, N., Battisti, E. (2011), Impresa, management e distorsioni comportamentali. Un approccio cognitivo alla gestione dell'impresa. L'Ego Biased Learning Approach, Torino: Giappichelli.

55. Monks, R.A.G., Minow, N. (2004), Corporate Governance, Oxford: Blackwell Publishing Ltd.

56. Morck, R., Wolfenzon, D., Yeung, B. (2005), Corporate Governance, Economic Entrenchment and Growth, Journal of Economic Literature, 43(3) (2005) 657--722.

57. Nestor, S., Thompson, J.K. (1999), Corporate Governance patterns in OECD economies: is convergence under way?, Seoul: OECD and Korea Development Institute Conference, Corporate Governance in Asia: A Comparative Perspective, (3-5 March 1999).

58. Nohria, N. (1992) Is network perspective a useful way of studying organizations? In N. Nohria \& R. G. Eccles (Eds.), Networks and organizations: Structure, form, and action: 1-22. Boston: Harvard Business School Press

59. Peng, M.W. (2003), Institutional transition and strategic choice, Academy of Management Review, 28 (2003) 275-296.

60. Pirson, M., Turnbull S. (2010), The Future of Corporate Governance: Network Governance - A Lesson from the Financial Crisis, Fordham University Schools of Business Research Paper, 10 (2010) 1-14.

61. Rajagopalan, N., Zhang, Y. (2008), Corporate governance reforms in China and India: Challenges and opportunities, Business Horizons, 51(1) (2008) 55-64.

62. Rajan, R.G., Raghuram, G., Zingales, L. (1998), Financial Dependence and Growth, American Economic Review, 88(3) (1998) 559-586.

63. Ring, P.S., Van de Ven, A.H. (1992), Structuring cooperative relationships between organizations. Strategic Management Journal, 13 (1992) 483-498.

64. Sheikh, R.A. (2011), SaaS BI: Sustainable Business Intelligence solutions for SMB'S, , International Journal of Research in Finance \& Marketing, 1(3) (2011) 1-11.

65. Shleifer, A., Vishny, R.W. (1997), A Survey of Corporate Governance, Journal of Finance, 52(02) (1997) 737-783.

66. Stiglitz, J.E., Muet, P.A. (edited by) (2001), Governance, Equity and Global Market, Annual Bank Conference on Development Economics - Europe, Oxford: Oxford University Press.

67. Tam, O.K. (1999), The Development of Corporate Governance in China, Cumberley Surrey: Edward Elgar Publishing.

68. Tardivo, G., Schiesari, R., Miglietta, N. (2012), Corporate Finance, Torino: Isedi.

69. Vijugin, O. (2004), International framework for corporate governance, Conference of Corporate Governance and Economic Growth in Russia, National Council on Corporate Governance.

70. Walter, C.E., Howie, F.J.T. (2003), Privatizing China: The Stock Markets and Their Role in Corporate Reform, New York: John Wiley.

71. Williamson, J.H. (1964), The economics of Discretionary Behaviour: Managerial Objectives, in AA.VV., A Theory of the Firm, Englewood Cliffs: Prentice Hall.

72. Young, M.N., Peng, M.W., Ahlstrom, D., Bruton, G.D., Jiang Y. (2008), Corporate Governance in Emerging Economies: A review of the Principal-Principal Perspective, Journal of Management Studies, 45(1) (2008) 196-219.

73. Zampi, V. (1995), Proprietà e governo delle imprese, Padova: Cedam. 